DOI 10.22460/jpmi.v1i3.219-228

\title{
KEMAMPUAN KOMUNIKASI MATEMATIS SISWA SMK
}

\author{
Tommy Tanu Wijaya ${ }^{1}$, M. Afrilianto ${ }^{2}$ \\ 1,2, IKIP Siliwangi, J1. Terusan Jenderal Sudirman, Cimahi, Jawa Barat, Indonesia \\ tanuwijayat@gmail.com ${ }_{2}^{1}$ muhammadafrilianto1@ikipsiliwangi.ac.id ${ }^{2}$
}

\begin{abstract}
This study aims to examine and analyze about: (1) Students are able to make conjecture, to formulate argument, to formulate definition and generalization, (2) Students are able to state daily life situation into mathematical language or symbol, (3) Students are able to relate real object, picture, and diagram to mathematics ideas, (4) Students are able to explain mathematics ideas, situation, and relation, verbal or written by using real object, picture, graphic, and algebra. This study was designed qualitative descriptive method. The population in this research is XI grade senior high school in Cimahi. Based on the results and discussion, students ability to make conjecture, to formulate argument, to formulate definition and generalization is low. students ability to state daily life situation into mathematical language or symbol are high. Students ability to relate real object, picture, and diagram to mathematics ideas is low. students ability to explain mathematics ideas, situation, and relation, verbal or written by using real object, picture, graphic, and algebra is low. This results provide for researcher to make further research on the mathematical communication ability for Senior High School in Cimahi.
\end{abstract}

Keywords : Mathematical Communication

\begin{abstract}
Abstrak
Penelitian ini bertujuan untuk menelaah dan menganalisis mengenai: (1) Kemampuan siswa dalam membuat konjektur, menyusun argumen, merumuskan definisi dan generalisasi, (2) Kemampuan siswa dalam menyatakan peristiwa sehari-hari dalam bahasa atau simbol matematika, (3) Kemampuan siswa dalam menghubungkan benda nyata, gambar, dan diagram ke dalam ide matematika, (4) Kemampuan siswa dalamn menjelaskan ide, situasi, dan relasi matematik secara lisan dan tulisan dengan benda nyata, gambar, grafik, dan aljabar. Metode dalam penelitian ini menggunakan metode deskriptif kualitatif. Populasi dalam penelitian ini adalah siswa kelas XI SMK TI Pembangunan Cimahi. Hasil penelitian menunjukkan bahwa kemampuan siswa dalam membuat konjektur, menyusun argumen, merumuskan definisi dan generalisasi tergolong rendah. Kemampuan siswa dalam menyatakan peristiwa sehari-hari dalam bahasa atau simbol matematika tergolong tinggi. Kemampuan siswa dalam menghubungkan benda nyata, gambar, dan diagram ke dalam ide matematika tergolong rendah. Kemampuan siswa dalam menjelaskan ide, situasi, dan relasi matematik secara lisan dan tulisan dengan benda nyata, gambar, grafik, dan aljabar tergolong rendah. Hasil ini menjadi dasar bagi peneliti untuk melakukan penelitian lanjutan mengenai kemampuan komunikasi matematis siswa SMK di Kota Cimahi.
\end{abstract}

Kata Kunci: Komunikasi Matematis

How to cite: Wijaya, T.T., Afrilianto, M. (2018). Kemampuan Komunikasi Siswa SMK. . JPMI - Jurnal Pembelajaran Matematika Inovatif, 1 (1), 53-60.

\section{PENDAHULUAN}


Matematika merupakan ilmu universal yang mendasari perkembangan teknologi modern dan berbagai disiplin ilmu serta mampu mengembangkan daya pikir manusia. Oleh karena itu, matematika perlu diajarkan di setiap jenjang pendidikan sebagai bekal pengembangan kemampuan menggunakan bahasa matematika dalam mengkomunikasikan ide atau gagasan matematika untuk memperjelas suatu situasi (Afrilianto, 2015).

Melihat betapa pentingnya matematika terutama dalam kehidupan sehari-hari, maka matematika perlu diajarkan. Cockroft (Haji, 2012) mengemukakan bahwa matematika perlu diajarkan karena: 1) Selalu digunakan dalam segala segi kehidupan, 2) Semua bidang studi memerlukan keterampilan matematika yang sesuai, 3) Merupakan sarana komunikasi yang kuat, singkat, dan jelas, 4) Dapat digunakan untuk menyajikan informasi dalam berbagai cara, 5) Meningkatkan kemampuan berpikir logis, ketelitian, dan kesadaran keruangan, dan 6) Memberikan kepuasan terhadap usaha memecahkan masalah yang menantang. Hal ini diwujudkan melalui proses pembelajaran matematika.

Tujuan pembelajaran matematika yang dirumuskan KTSP (Suparno, 2001:346) menyatakan bahwa belajar matematika bertujuan agar peserta didik mampu memahami konsep matematika, menggunakan penalaran, memecahkan masalah, mengomunikasikan gagasan dengan simbol, tabel, diagram atau media lain untuk memperjelas keadaan atau masalah serta memiliki sikap menghargai kegunaan matematika dalam kehidupan. Untuk mencapai tujuan pembelajaran matematika, salah satu aspek yang harus dikuasai siswa adalah kemampuan komunikasi matematis.

Kemampuan komunikasi matematis merupakan salah satu aspek dalam standar proses pembelajaran matematika menurut rekomendasi National Council of Teacher Mathematics (Herdian, 2010:12). Indikator standar proses komunikasi yang direkomendasikan NCTM meliputi 1) Mengatur dan menggabungkan ide matematis siswa melalui komunikasi, 2) Mengkomunikasikan ide matematis siswa secara koheren dan jelas kepada siswa lain, guru, maupun dengan yang lainnya, 3) Menganalisis dan mengevaluasi ide dan strategi matematis orang lain, dan 4) Menggunakan bahasa matematika untuk menyatakan ide matematis dengan tepat.

Hendriana, Rohaeti dan Sumarmo (2017:59) menyatakan bahwa komunikasi matematis merupakan satu kemampuan dasar matematis yang esensial dan perlu dimiliki oleh siswa sekolah menengah (SM). Menurut Sumarmo (2012:14), komunikasi matematis meliputi kemampuan siswa, dalam: (1) Menghubungkan benda nyata, gambar, dan diagram ke dalam ide matematika, (2) Menjelaskan ide, situasi dan relasi matematik secara lisan dan tulisan dengan benda nyata, gambar, grafik dan aljabar, (3) Menyatakan peristiwa sehari-hari dalam bahasa atau simbol matematika, (4) Mendengarkan, berdiskusi dan menulis tentang matematika, (5) Membaca dengan pemahaman suatu presentasi matematika tertulis, (6) Membuat konjektur, menyusun argumen, merumuskan definisi dan generalisasi, (7) Mengungkapkan kembali suatu uraian atau paragraf matematika dalam bahasa sendiri.

Berdasarkan pemaparan tersebut, kemampuan komunikasi matematis penting dimiliki oleh siswa. Namun hasil Programme International for Student Assesment (PISA) tahun 2012 (Suryadi, 2012:8) menunjukkan bahwa kemampuan komunikasi matematis siswa Indonesia masih rendah. Berdasarkan rata-rata skor literasi matematika, Indonesia menempati peringkat 64 dari 65 negara yang berpartisipasi dan memperoleh skor 375 dari rata-rata skor yang ditetapkan Organisation for Economic Cooperation and Development (OECD) yaitu 494. Kemampuan komunikasi termasuk salah satu aspek yang diamati dalam PISA. Salah satu 
penyebabnya menurut Aryans (2007:1-2) adalah pada umumnya siswa Indonesia kurang terlatih dalam menyelesaikan soal-soal dengan karakteristik seperti pada soal-soal PISA yang menuntut argumentasi dalam penyelesaiannya.

Penelitian ini merupakan hasil observasi awal. Tujuan penelitian ini untuk menelaah kemampuan komunikasi matematis siswa kelas XI SMK di Kota Cimahi pada materi Barisan dan Deret. Ketika kemampuan komunikasi matematis siswa telah diketahui, selanjutnya guru perlu merancang pembelajaran yang memfasilitasi dan membiasakan siswa untuk melakukan komunikasi matematis, sehingga kemampuan siswa tersebut dapat meningkat.

\section{METODE}

Metode dalam penelitian ini menggunakan metode deskriptif kualitatif. Penelitian deskriptif dapat dibagi dalam beberapa jenis yaitu: metode survey, metode deskriptif berkesinambungan (continuity descriptive), penelitian studi kasus, penelitian analisis pekerjaan dan aktivitas, penelitian tindakan (action research), penelitian perpustakaan dan dokumenter (Nazir, 2005:55). Bentuk penelitian yang digunakan dalam penelitian ini adalah penelitian studi kasus. "Subjek adalah orang/individu/kelompok yang dijadikan unit atau satuan (kasus) yang diteliti" (Ridwan, 2003:17). Populasi dalam penelitian ini adalah siswa kelas XI SMK TI Pembangunan Cimahi, dengan sampel sebanyak 22 orang siswa.

Menurut Arikunto (2009:20), “Objek segala sesuatu yang menjadi titik pusat pengamatan karena penilai menginginkan informasi tentang sesuatu tersebut". Objek dalam penelitian ini adalah kemampuan komunikasi matematis siswa pada pembelajaran barisan dan deret. Teknik pengumpulan data yang digunakan dalam penelitian ini adalah teknik pengukuran dan teknik komunikasi langsung. Menurut Nawawi (2005:95), pengukuran adalah suatu usaha untuk mengetahui suatu keadaan berupa kecerdasan, kecakapan nyata (achievement) dalam bidang tertentu, dan teknik komunikasi langsung merupakan usaha peneliti mengadakan kontak langsung secara lisan atau tatap muka dengan sumber data. Tes yang digunakan pada penelitian ini adalah tes tertulis yang berbentuk uraian yang telah teruji validitas, daya pembeda, dan indeks kesukarannya.

Prosedur dalam penelitian ini terdiri dari 3 tahap, yaitu: 1) Tahap persiapan, 2) Tahap pelaksanaan, 3) Tahap akhir. Langkah-langkah tahap persiapan yang dilakukan pada tahap persiapan, antara lain: (1) Melakukan komunikasi awal ke sekolah; (2) Menyiapkan instrumen penelitian untuk tes soal tes kemampuan komunikasi matematis; (3) Merevisi instrumen penelitian berdasarkan hasil validasi. Tahap Pelaksanaan: (1) Memberikan tes kepada siswa kelas XI SMK TI Pembangunan Cimahi, (2) Menganalisis jawaban siswa. Tahap akhir 1. Menganalisis data yang diperoleh hasil tes, mendeskripsikan hasil analisis data dan memberikan kesimpulan sebagai jawaban dari rumusan masalah, dan menyusun hasil penelitian.

\section{HASIL DAN PEMBAHASAN}

Penelitian ini dilaksanakan pada salah satu kelas XI di SMK TI Pembanguan Cimahi. Sesuai dengan pertanyaan penelitian, maka dilakukan pembahasan dan analisis jawaban untuk mengungkap kemampuan komunikasi matematis yang dilakukan siswa dari setiap jawaban soal tes yang diberikan. Mendeskripsikan kemampuan komunikasi siswa dalam menyelesaikan soal 
pada materi barisan dan deret pada tiap soal. Data dari hasil penelitian ini yaitu berupa hasil tes siswa yang pengumpulan datanya menggunakan instrumen soal tes berupa uraian sebanyak 5 soal.

Tabel 1. Deskripsi Kemampuan Siswa dalam Membuat Konjektur, Menyusun Argumen, Merumuskan Definisi dan Generalisasi.

\begin{tabular}{l|l}
\hline $\begin{array}{l}\text { Kode } \\
\text { Siswa }\end{array}$ & $\begin{array}{l}\text { Jumlah } \\
\text { Skor }\end{array}$ \\
\hline 001 & 3 \\
\hline 002 & 3 \\
\hline 003 & 3 \\
\hline 004 & 3 \\
\hline 005 & 3 \\
\hline Jumlah & 15 \\
\hline $\begin{array}{l}\text { Persentase } \\
(\%)\end{array}$ & $38 \%$ \\
\hline
\end{tabular}

Berdasarkan Tabel 1 tersebut menunjukkan bahwa kemampuan siswa dalam membuat konjektur, menyusun argumen, merumuskan definisi dan generalisasi pada soal nomor 1 dengan persentase $37,5 \%$.

Tabel 2. Deskripsi Kemampuan Siswa dalam Menyatakan Peristiwa Sehari-hari dalam Bahasa atau Simbol Matematika.

\begin{tabular}{l|l}
\hline Kode Siswa & Jumlah Skor \\
\hline 001 & 6 \\
\hline 002 & 12 \\
\hline 003 & 12 \\
\hline 004 & 10 \\
\hline 005 & 12 \\
\hline Jumlah & 52 \\
\hline $\begin{array}{l}\text { Persentase } \\
(\%)\end{array}$ & $86.7 \%$ \\
\hline
\end{tabular}

Berdasarkan Tabel 2 tersebut menunjukkan bahwa kemampuan siswa dalam menyatakan peristiwa sehari-hari dalam bahasa atau simbol matematika pada soal nomor 2 dengan persentase $86,7 \%$.

Tabel 3. Deskripsi Kemampuan Siswa dalam Menghubungkan Benda Nyata, Gambar, dan Diagram ke dalam Ide Matematika.

\begin{tabular}{l|l}
\hline Kode Siswa & Jumlah Skor \\
\hline 001 & 3 \\
\hline 002 & 6 \\
\hline 003 & 6 \\
\hline 004 & 5 \\
\hline 005 & 9 \\
\hline Jumlah & 29 \\
\hline Persentase (\%) & $48.3 \%$ \\
\hline
\end{tabular}


Berdasarkan Tabel 3 tersebut menunjukan bahwa kemampuan siswa dalam menghubungkan benda nyata, gambar, dan diagram ke dalam ide matematika pada soal nomor 3 dengan persentase $48.3 \%$.

Tabel 4. Deskripsi Kemampuan Siswa dalam Menjelaskan Ide, Situasi, dan Relasi Matematik Secara Lisan dan Tulisan dengan Benda Nyata, Gambar, Grafik, dan Aljabar.

\begin{tabular}{l|l}
\hline Kode siswa & Jumlah Skor \\
\hline 001 & 3 \\
\hline 002 & 0 \\
\hline 003 & 0 \\
\hline 004 & 3 \\
\hline 005 & 9 \\
\hline Jumlah & 15 \\
\hline $\begin{array}{l}\text { Persentase } \\
(\%)\end{array}$ & $25 \%$ \\
\hline
\end{tabular}

Berdasarkan Tabel 4 tersebut menunjukkan bahwa kemampuan siswa dalam menjelaskan ide, situasi, dan relasi matematik secara lisan dan tulisan dengan benda nyata, gambar, grafik, dan aljabar pada soal nomor 4 dengan persentase $25 \%$.

Persentase rata-rata kemampuan siswa dalam membuat konjektur, menyusun argumen, merumuskan definisi dan generalisasi pada soal nomor 1 dengan persentase adalah $37,5 \%$. Hal ini berarti sebagian besar siswa masih kurang dalam membuat konjektur, menyusun argumen, merumuskan definisi dan generalisasi. Persentase rata-rata kemampuan siswa dalam menyatakan peristiwa sehari-hari dalam bahasa atau simbol matematika adalah $86,7 \%$. Hal ini berarti hampir seluruh siswa mampu menyatakan peristiwa sehari-hari dalam bahasa atau simbol matematika. Hal ini menunjukan bahwa pada soal nomor 2 siswa telah mampu menyatakan peristiwa sehari-hari dalam bahasa atau simbol matematika.

Persentase rata-rata kemampuan siswa dalam menghubungkan benda nyata, gambar, dan diagram ke dalam ide matematika adalah $48,3 \%$. Hal ini berarti masih cukup banyak siswa yang tidak mampu menghubungkan benda nyata, gambar, dan diagram ke dalam ide matematika. Persentase rata-rata kemampuan siswa dalam menjelaskan ide, situasi, dan relasi matematik secara lisan dan tulisan dengan benda nyata, gambar, grafik, dan aljabar adalah $25 \%$. Hal ini berarti sebagian besar siswa tidak mampu dalam menjelaskan ide, situasi, dan relasi matematik secara lisan dan tulisan dengan benda nyata, gambar, grafik, dan aljabar.

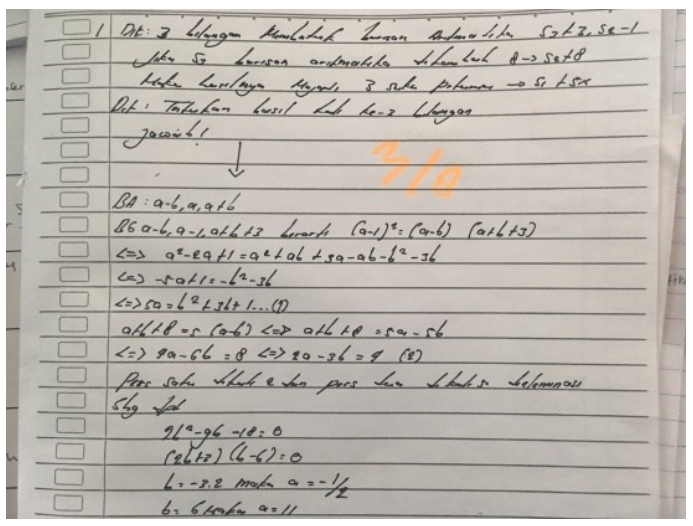

Gambar 1 
Pada soal nomor 1 terlihat bahwa siswa mengalami kesulitan untuk merumuskan definisi dan generalisasi. Terlihat bahwa dari 5 orang siswa, 3 orang dapat merumuskan, tetapi rumus yang dibuat kurang tepat dan 2 orang tidak dapat merumuskan.

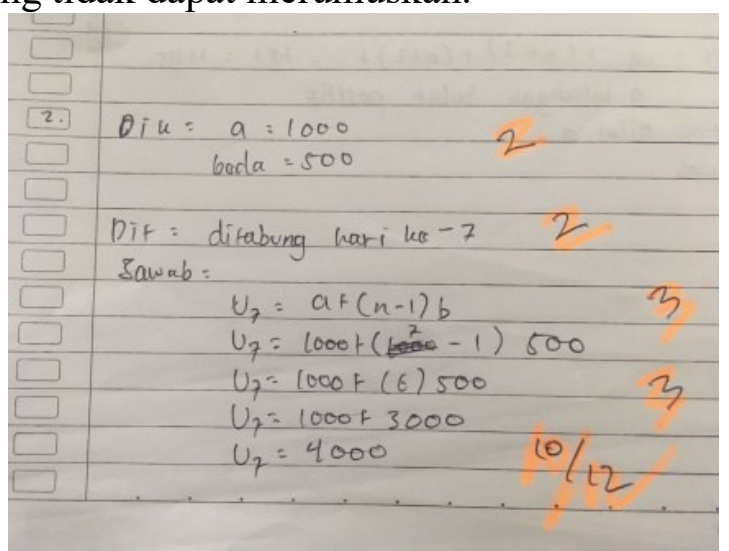

\section{Gambar 2}

Pada soal nomor 2 terlihat bahwa siswa cukup baik dalam menyatakan peristiwa sehari-hari ke dalam bahasa matematika. Terlihat bahwa dari 5 orang siswa, 4 orang siswa dapat mengerjakan dengan benar, sedangkan 1 orang mengerjakan tetapi tidak sistematis.

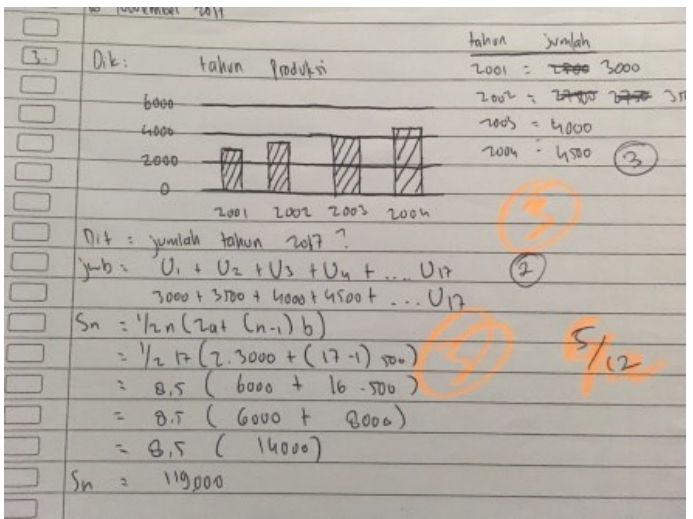

Gambar 3

Pada soal nomor 3 terlihat bahwa siswa masih kurang dalam menghubungkan diagram ke dalam ide matematika. Terlihat bahwa dari 5 orang siswa, 2 orang siswa dapat mengerjakan dengan benar, sedangkan 2 orang mengerjakan tetapi belum lengkap dan jawabannya salah, bahkan 1 orang yang tidak mengerjakan sama sekali

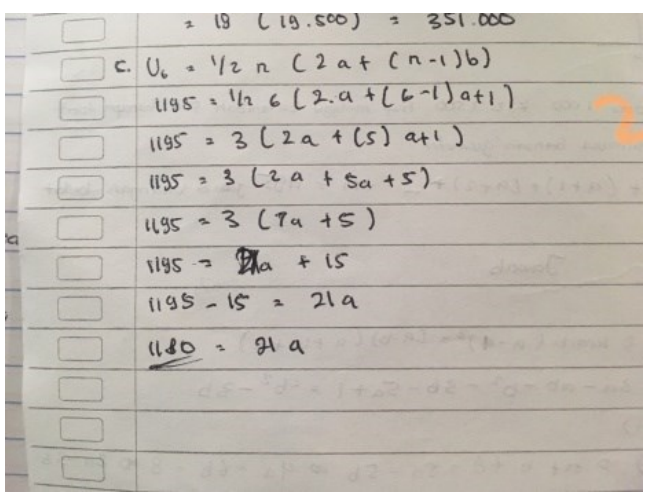

Gambar 4 
Pada soal nomor 4 terlihat bahwa siswa tidak mampu dalam menjelaskan ide atau situasi ke dalam bentuk aljabar. 3 orang siswa dapat menjelaskan ide tetapi jawaban yang dibuat masih kurang tepat, sedangkan 2 orang siswa lainnya tidak dapat menjelaskan ide.

\section{KESIMPULAN DAN SARAN}

Berdasarkan hasil penelitian dan pembahasan penelitian, disimpulkan bahwa kemampuan siswa dalam membuat konjektur, menyusun argumen, merumuskan definisi dan generalisasi tergolong rendah. Kemampuan siswa dalam menyatakan peristiwa sehari-hari dalam bahasa atau simbol matematika tergolong tinggi. Kemampuan siswa dalam menghubungkan benda nyata, gambar, dan diagram ke dalam ide matematika tergolong rendah Kemampuan siswa dalam menjelaskan ide, situasi, dan relasi matematik secara lisan dan tulisan dengan benda nyata, gambar, grafik, dan aljabar tergolong rendah. Hasil ini menjadi dasar bagi peneliti untuk melakukan penelitian lanjutan mengenai kemampuan komunikasi matematis siswa SMK di Kota Cimahi.

Berdasarkan hasil penelitian yang diperoleh, peneliti memberikan saran sebagai berikut: (1) Siswa SMK hendaknya dilatih secara khusus mengenai kemampuan komunikasi matematis; (2) Diperlukan penelitian lanjutan mengenai pencapaian dan peningkatan kemampuan komunikasi matematis.

\section{DAFTAR PUSTAKA}

Afrilianto, M. (2015). Pengaruh Pendekatan Model-Eliciting Activities Terhadap Kemampuan Komunikasi Matematik Siswa SMP. Jurnal Ilmiah UPT P2M STKIP Siliwangi. Vol. 2, No. 1, hal. 40.

Arikunto, S. (2009). Dasar-Dasar Evaluasi Pendidikan. Jakarta: Bumi Aksara.

Aryans (2007). Komunikasi dalam Matematika. (Online). Tersedia: http://rbaryans.wordpress.com. (Diakses November 2017).

Haji, S. (2012). Pengaruh Pembelajaran Kontekstual Terhadap Kemampuan Komunikasi Matematika Siswa SMP Kota Bengkulu. Jurnal Exacta. Vol. X. (Online). Tersedia: http://www.Salehhaji.com. (Diakses November 2017).

Hendriana, H., Rohaeti, E.E., Sumarmo, U. (2017). Hard Skills dan Soft Skills Matematik Siswa. Bandung: Refika Aditama.

Herdian (2010). Kemampuan Komunikasi Matematika. (Online). Tersedia: http://herdy07.wordpress.com/2010/05/27/kemampuan-komunikasimatematis. (Diakses November 2017).

Nazir, M. (2005). Metode Penelitian. Jakarta: Ghalia Indonesia.

Nawawi, H. (2005). Metode Penelitian Bidang Sosial. Yogyakarta: Gajah Mada University Press.

Ridwan (2003). Dasar-Dasar Statistika. Bandung: Alfabeta.

Sumarmo, U. (2012). Bahan Ajar Matakuliah Proses Berpikir Matematik Program S2 Pendidikan Matematika STKIP Siliwangi Bandung. Cimahi: Tidak diterbitkan.

Suparno (2001). Membangun Kompetensi Belajar. Jakarta: Dirjen Dikti Depdiknas. 
Suryadi, D. (2012). Komunikasi Matematika dan Pendidikan Matematika Realistik. (Online). Tersedia: http://bundaiza.files.wordpress.com/2012/12/komunikasi_matematik_dan_pmrprosiding.pdf. (Diakses November 2017). 